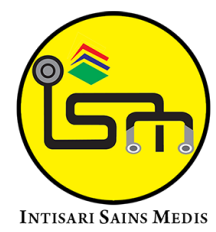

Published by Intisari Sains Medis

\title{
Pengukuran Interleukin-6 (IL-6), C-Reactive Protein (CRP) dan D-Dimer sebagai prediktor prognosis pada pasien COVID-19 gejala berat: sebuah tinjauan pustaka
}

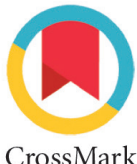

I Ketut Wardika ${ }^{1 *}$, I Gusti Putu Hery Sikesa ${ }^{2}$

\section{ABSTRACT}

Background: Patients with severe symptoms of Coronavirus disease-19 (COVID-19) experience a cytokine storm and coagulopathy that contribute to increased mortality requires a clinical parameter that is useful for risk stratification of COVID-19 patients. This literature review will discuss further the role of measuring D-Dimer, CRP and IL-6 levels as predictors of severe COVID-19 symptoms and prognostic predictors in severe COVID-19 patients.

Methods: This literature review involved the relevant literature on CRP, IL-6, D-dimer and COVID-19. Different data sources or manual literature search methods were used to search for articles related to the literature topic. Results: In COVID-19, severe hyperinflammatory response cytokine storm symptoms were characterized by the release of excessive proinflammatory cytokines such as IL-6 and an increase in CRP as an acute phase reactant. In addition, there is also a coagulopathy condition which is characterized by an increase in D-dimer. There were significant differences in CRP, IL-6 and D-dimer levels between COVID-19 patients with mild and severe symptoms. levels of CRP, IL- 6 and D-dimer also showed a significant relationship with increased severity and mortality.

Conclusion: Measurement of CRP, IL- 6 and D-dimer levels is useful for predicting the occurrence of severe COVID-19 symptoms and a prognostic predictor in patients with severe COVID-19 symptoms.

Keywords: COVID-19, CRP, D-Dimer, Interleukin-6, SARS-CoV-2.

Cite This Article: Wardika, I.K., Sikesa, I.G.P.H. 2021. Pengukuran Interleukin-6 (IL-6), C-Reactive Protein (CRP) dan D-Dimer sebagai prediktor prognosis pada pasien COVID-19 gejala berat: sebuah tinjauan pustaka. Intisari Sains Medis 12(3): 901-907. D0I: 10.15562/ism.v12i3.1158

'Dokter Umum, RS Surya Husadha, Denpasar, Indonesia;

${ }^{2}$ Dokter Spesialis Penyakit Dalam, RSUD Payangan, Gianyar, Indonesia;

\section{*Korespondensi:}

I Ketut Wardika;

Dokter Umum, RS Surya Husadha, Denpasar, Indonesia;

war_dika77@yahoo.co.id

Diterima: 02-10-2021

Disetujui: 05-12-2021

Diterbitkan: 20-12-2021 berkaitan dengan topik literatur.

Hasil: Pada infeksi COVID-19 gejala berat terjadi badai sitokin akibat respon hiperinflamasi ditandai dengan dilepasnya sitokin pro-inflamasi berlebih seperti IL-6 serta peningkatan CRP sebagai reaktan fase akut. Selain itu terjadi pula kondisi koagulopati yang ditandai dengan peningkatan D-dimer. Terdapat perbedaan kadar CRP, IL-6 dan D-dimer yang signfikan antara pasien COVID-19 dengan gejala ringan dan gejala berat. Peningkatan kadar CRP, IL-6 dan D-dimer juga menunjukkan hubungan signifikan dengan peningkatan keparahan infeksi serta mortalitas.

Simpulan: Pengukuran kadar CRP, IL-6 dan D-dimer bermanfaat sebagai prediktor terjadinya COVID-19 
gejala berat dan prediktor prognostik pada pasien COVID-19 gejala berat.

Kata kunci: COVID-19, CRP, D-Dimer, Interleukin-6, SARS-CoV-2.

Sitasi Artikel ini: Wardika, I.K., Sikesa, I.G.P.H. 2021. Pengukuran Interleukin-6 (IL-6), C-Reactive Protein (CRP) dan D-Dimer sebagai prediktor prognosis pada pasien COVID-19 gejala berat: sebuah tinjauan pustaka. Intisari Sains Medis 12(3): 901-907. D0I: 10.15562/ism.v12i3.1158

\section{PENDAHULUAN}

Infeksi Coronavirus Disease-2019 (COVID-19) yang disebabkan oleh virus SARS-CoV-2 telah menjadi pandemi di seluruh dunia sejak pertama kali ditemukan di Wuhan, Cina pada akhir Desember 2019. ${ }^{1}$ Kasus COVID-19 secara global telah mencapai 219 juta kasus dan menyebabkan kematian sebanyak 4,55 juta jiwa. $^{2}$ Di Indonesia sendiri angka kejadian COVID-19 secara kumulatif mencapai 4,21 juta kasus dengan angka kematian sebanyak 141.000 jiwa. $^{3}$ Hingga saat ini belum ditemukan terapi antivirus untuk mengatasi virus SARS-CoV-2, selain itu identifikasi kasus COVID-19 juga masih menjadi tantangan karena spektrum gejala klinis infeksi COVID-19 sangat luas mulai dari asimtomatik, gejala ringan-sedang hingga gejala berat. ${ }^{4}$ Pasien dengan gejala ringan dapat mengalami gejala yang tidak spesifik seperti demam, batuk, lemas, diare, nyeri kepala dan nyeri tenggorokan. Sedangkan pasien dengan gejala berat dapat mengalami sesak, sianosis, takipnoe, nyeri dada, pingsan hingga kondisi yang lebih berat seperti Acute Respiratory Distress Syndrome (ARDS). Infeksi COVID-19 tidak hanya mengakibatkan beban sistem kesehatan yang meningkat, namun juga berimplikasi pada meningkatnya angka mortalitas, dimana biasanya terjadi pada pasien COVID-19 kriteria berat. ${ }^{1,4}$

Respon inflamasi memainkan peran penting dalam progresi COVID-19, dimana terjadinya bada sitokin meningkatkan keparahan infeksi yang dapat menyebabkan komplikasi berat hingga kematian. Dalam Panduan Diagnosis dan Tatalaksana COVID-19 edisi kelima direkomendasikan monitoring kadar sitokin inflamasi untuk meningkatkan efikasi penatalaksanaan dan dapat menurunkan angka mortalitas. Salah satu sitokin inflamasi yang disebutkan adalah Interleukin-6 yang ditemukan meningkat selama infeksi COVID-19.5,6 Interleukin-6 merupakan sitokin pro-inflamasi yang disintesis oleh berbagai sel parenkim paru dimana peningkatan jumlah IL-6 merefleksikan kondisi inflamasi berat pada paru. ${ }^{7}$

Selain itu saat terjadinya badai sitokin pada infeksi COVID-19 kriteria berat, juga ditemukan kadar C-reactive protein (CRP). CRP merupakan protein non spesifik fase akut yang diinduksi oleh IL-6 dan diproduksi di hati sebagai respon terjadinya inflamasi, infeksi serta kerusakan jaringan. Kadar CRP pada kondisi normal biasanya rendah, namun selama inflamasi terjadi kadarnya akan meningkat pesat. Sebagai lini pertama pertahanan tubuh pada sistem imun bawaan terhadap infeksi virus, kadar CRP yang meningkat berhubungan dengan produksi berlebihan sitokin proinflamasi pada pasien COVID-19 kriteria berat dan mengarah pada terjadinya disfungsi organ tahap lanjut pada pasien COVID-19.8,9

Studi terbaru menunjukkan, mortalitas akibat infeksi COVID-19 gejala berat berhubungan dengan adanya koagulopati dan Disseminated Intravascular Coagulation (DIC) yang ditandai dengan meningkatnya nilai D-Dimer. D-dimer merupakan produk degradasi fibrin yang terbentuk selama proses degradasi bekuan darah oleh fibrinolisis. Peningkatan D-dimer dalam darah merupakan penanda kecurigaan trombosis. Peningkatan D-dimer ditemukan pada trombosis vena dalam, emboli paru, trombosis arteri, DIC, kehamilan, inflamasi, kanker, penyakit liver kronis, trauma, pembedahan, dan vaskulitis. ${ }^{10}$ Peningkatan D-dimer sering ditemukan pada pasien COVID-19 berat dan merupakan prediktor terjadinya ARDS, kebutuhan perawatan di unit perawatan intensif, dan kematian. Studi oleh Zhou et al., menunjukkan bahwa peningkatan $\mathrm{D}$-dimer $>1,0 \quad \mu \mathrm{l} / \mathrm{mL}$ merupakan prediktor terkuat terjadinya mortalitas pada pasien COVID-19. ${ }^{1}$

Sejumlah studi telah dilakukan untuk mengidentifikasi peranan parameter inflamasi berupa D-Dimer, CRP dan Interleukin-6 sebagai prediktor terjadinya COVID-19 gejala berat maupun sebagai prediktor prognosis pada pasien COVID-19 gejala berat..$^{7-9,11-12}$ Diindentifikasinya parameter klinis serta laboratoris yang dapat menjadi prediktor prognosis pada infeksi COVID-19 gejala berat sangat diperlukan dalam penatalaksanaan COVID-19. Prediktor prognostik tersebut akan membantu manajemen klinis, stratifikasi risiko serta pendekatan yang lebih maksimal pada pasien dengan risiko tinggi kematian akibat COVID-19. Dengan dilakukannya stratifikasi risiko pada pasien dengan infeksi COVID-19 gejala berat dapat membantu mengelompokkan pasien dengan risiko mortalitas tinggi sehingga meningkatkan pemahaman klinis akan kondisi pasien dan diberikannya penatalaksanaan optimal. ${ }^{7,9,10}$ Berdasarkan pada pemaparan di atas, tinjauan pustaka ini mencoba membahas lebih lanjut mengenai peran pengukuran kadar D-Dimer, CRP dan IL-6 sebagai prediktor terjadinya COVID-19 gejala berat dan prediktor prognostik pada pasien COVID-19 gejala berat.

\section{Kaitan D-Dimer, CRP dan IL-6 pada Patofisiologi Infeksi COVID-19 Kriteria Berat}

Infeksi COVID-19 disebabkan oleh virus Severe Acute Respiratory Syndrome Coronavirus Disease (SARS CoV-2) dengan materi genetik rantai tunggal yang berikatan dengan reseptor angiotensin converting enzyme 2 (ACE-2) pada tubuh manusia. Reseptor ACE-2 terdapat pada seluruh bagian tubuh manusia, namun mayoritas ditemukan pada sel epitel saluran nafas. Setelah virus SARS-CoV-2 
memasuki tubuh melalui reseptor ACE-2 pada sel saluran nafas, virus melepaskan molekul patogen associated molecular patterns (PAMP) dan damage associated molecular patterns (DAMP) (Gambar 1).,5

Dilepasnya PAMP dan DAMP direspon oleh tubuh dengan dikeluarkannya sitokin pro-inflamasi seperti Interleukin-6, C-X-C motif chemokine-10 (CXCL10), macrophage inflammatory protein $1 a$ (MIP1a), macrophage inflammatory protein $1 b$ (MIP1b) dan monocyte chemoattractant protein 1 (MCP1). Sitokin-sitokin proinflamasi inilah yang kemudian merekrut monosit, makrofag dan sel T ke jaringan lokal, menyebabkan pelepasan sitokin pro-inflamasi lebih banyak yang menyebabkan terjadinya badai sitokin seperti yang ditunjukkan oleh Gambar 1. Bukti terjadinya badai sitokin ini didukung oleh temuan sejumlah studi yang mengkonfirmasi peningkatan berbagai sitokin inflamasi pada pasien dengan COVID-19 gejala berat yang dirawat di unit perawatan intensif. ${ }^{5,6,13}$

Interleukin-6 merupakan sitokin proinflamasi yang disintesis oleh berbagai sel parenkim paru, termasuk makrofag alveolar, pneumosit, limfost $\mathrm{T}$ dan fibroblast paru. IL-6 merupakan sitokin pleiotropik yang berperan penting dalam regulasi respon imun dan inflamatori. Kadar IL-6 pada fase akut merefleksikan kondisi inflamasi pada paru. Inflamasi sistemik yang terjadi pada infeksi COVID-19 juga dapat mengarah pada kondisi lebih berat yakni terjadinya sepsis dan kegagalan multi organ. ${ }^{7,14}$ Pada kondisi infeksi, inflamasi serta kerusakan jaringan akan ditemukan kadar CRP yang meningkat. CRP merupakan protein nonspesifik fase akut yang diproduksi di hati dan diinduksi oleh IL-6. Pada kondisi badai sitokin, akan dihasilkan sitokin proinflamasi berlebih termasuk salah satunya IL-6. Jumlah IL-6 yang meningkat tentunya akan meningkatkan kadar CRP dalam darah. ${ }^{8,9}$ Sebagai salah satu reaktan fase akut, kadar CRP akan meningkat pesat setelah terjadinya inflamasi, kerusakan sel dan jaringan. Infeksi pada paru dengan adanya inflamasi biasanya akan meningkatkan kadar CRP sebagai respons dilepaskannya sitokin inflamasi seperti IL-6, IL-1 atau TNF- $\alpha$. Hal ini juga ditemukan pada pasien COVID-19 kriteria berat dimana peningkatan kadar CRP konsisten dengan peningkatan kadar sejumlah sitokin proinflamasi seperti IL6. Pada kondisi inflamasi, CRP berperan dengan berikatan dengan patogen dan memicu eliminasi patogen via sel fagositik. Namun meningkatnya ekspresi sitokin pro-inflamasi, juga menyebabkan efek inflamasi berlebih oleh CRP. Efek inflamasi berlebih tersebut bertanggung jawab terhadap terjadinya progresi penyakit menjadi lebih buruk dan bahkan

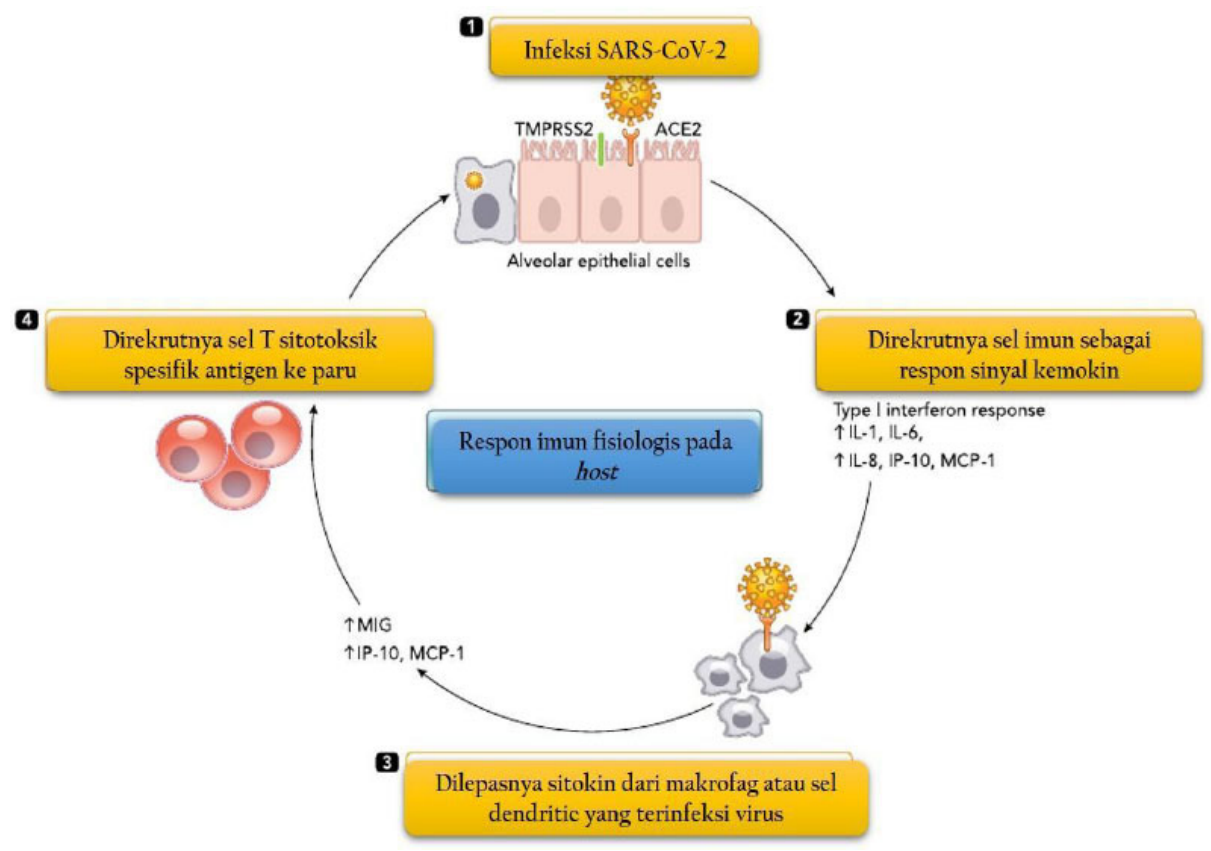

Gambar 1. Respon imun host terhadap infeksi virus SARS-CoV-2. ${ }^{6}$ kematian. ${ }^{8,15,16}$

Pada infeksi COVID-19 kriteria berat juga dapat terjadi komplikasi fatal berupa imunotrombosis yang diakibatkan oleh kondisi hiperinflamasi dan badai sitokin. Imunotrombosis merupakan fenomena yang terjadi akibat pertahanan host melawan berbagai patogen, termasuk infeksi virus. ${ }^{5,6}$ Sebagai contoh, aktivasi jalur komplemen dapat menginisiasi kaskade koagulasi. Pada pasien dengan infeksi COVID-19 diamati adanya kerusakan jaringan paru dimediasi komplemen dan kerusakan mikrovaskular. Hal tersebut memicu respon prokoagulan yang juga berhubungan dengan efek inflamatori sitokin pada endotel vascular, meliputi peningkatan permeabilitas dan kerusakan vaskuler akibat infiltrasi sel imun. Kondisi hiperkoagulasi dan disseminated intravascular coagulopathy (DIC) merupakan kondisi yang sering ditemukan pada pasien dengan infeksi virus, termasuk infeksi COVID-19. ${ }^{10-12}$ Hiperkoagulasi terjadi karena respon hiperinflamasi berupa koagulasi dan aktivasi platelet berlebih. Respon prothrombin berlebih terjadi untuk mencegah kerusakan alveolar dan mencegah patogen infeksius masuk ke aliran darah. Namun hal tersebut juga menyebabkan peningkatan pembentukan mikrotrombus pulmoner. ${ }^{5,6,12}$

Hiperkoagulasi ditandai dengan peningkatan kadar D-dimer. D-Dimer merupakan penanda koagulasi dan pembentukan thrombus. D-dimer merupakan produk hasil degradasi fibrin yang terjadi akibat adanya konversi fibrinogen menjadi fibri yang dimediasi oleh thrombin, retikulasi fibrin yang dimediasi oleh faktor XIII dan degradasi fibrin oleh plasmin. Kadar D-dimer bergantung pada proses koagulasi dan aktivasi fibrinolysis. Kadar D-dimer memiliki sensitivitas tinggi untuk terjadinya penyakit tromboemboli, namun memiliki spesifisitas yang rendah karena D-dimer juga ditemukan meningkat pada kondisi lain seperti sepsis dan ARDS. Adanya perubahan koagulasi berupa peningkatan kadar D-Dimer ditemui pada pasien dengan infeksi COVID-19.6,11,12 Penelitian oleh Li et al menemukan rerata kadar D-dimer yang signifikan lebih tinggi pada pasien COVID-19 yang meninggal 
dibandingkan pasien COVID-19 yang bertahan hidup. ${ }^{11}$ Beberapa studi terdahulu juga mengamati kadar D-dimer yang meningkat secara kontinyu pada pasien dengan infeksi COVID-19 kriteria berat hingga pasien tersebut meninggal dibandingkan dengan pasien COVID-19 yang bertahan hidup. ${ }^{17-19}$

Peran Pengukuran Interleukin (IL-6) dan C-Reactive Protein (CRP) sebagai Prediktor Prognosis pada Pasien COVID-19 Kriteria Berat

Selama ini telah dilakukan sejumlah penelitian terkait peranan pengukuran kadar CRP, Interleukin-6 dan D-Dimer sebagai prediktor terjadinya COVID-19 dan prediktor prognosis pada pasien COVID-19 kriteria berat. Seperti studi observasional retropektif lainnya oleh Luo et al yang meneliti rekam medis pasien dengan infeksi COVID-19 menemukan bahwa nilai serum CRP saat awal masuk rumah sakit bermanfaat sebagai diskriminator keparahan infeksi COVID-19.16 Sebagai salah satu reaktan fase akut, CRP meningkat dengan pesat pada awal terjadinya inflamasi, serta kerusakan sel dan jaringan. Penyakit paru dengan adanya inflamasi biasanya memiliki karakteristik berupa peningkatan kadar serum CRP sebagai respon terhadap sitokin inflamasi seperti IL-6, IL-1 atau TNF-a. Adanya hubungan antara kadar serum CRP yang tinggi dengan luaran klinis yang buruk juga dijumpai pada pasien dengan ARDS dan pada pasien lanjut usia, kadar CRP yang tinggi berkorelasi dengan kematian. Kadar CRP yang meningkat signifikan pada pasien COVID-19 mengindikasikan adanya stress inflamatori berlebih dan berkontibusi terhadap timbulnya gejala klinis berat dan bahkan kematian pada pasien COVID-19. Studi tersebut merekomendasikan pengukuran kadar CRP saat awal rawat inap untuk menentukan keparahan infeksi dan memprediksi luaran klinis pada pasien COVID-19. ${ }^{16}$

Yang kedua, penelitian observasional retrospektif oleh Chen et al menemukan bahwa kadar CRP plasma yang lebih tinggi mengindikasikan pneumonia akibat COVID-19 yang lebih berat dan durasi perawatan yang lebih lama. ${ }^{9}$ Kadar CRP plasma berkorelasi positif dengan keparahan pneumonia akibat COVID-19. Konsentrasi CRP diketahui meningkat secara signifikan sebanyak $11,47 \mathrm{mg} / \mathrm{L}$ dan $23.40 \mathrm{mg} / \mathrm{L}$ pada pasien infeksi COVID-19 kriteria sedang dan berat. Penelitian tersebut menemukan nilai titik potong untuk stratifikasi pasien COVID-19 dengan gejala ringan dan berat sebesar 16,60 mg/L dengan sensitivitas sebesar $77 \%$ dan spesifisitas $72 \% .{ }^{9}$

Kadar CRP meningkat pada 24-72 jam pasca paparan dengan stimulus dan akan turun secara eksponensial

Tabel 1. Studi terkait peranan C-Reactive Protein (CRP) dan Interleukin-6 (IL-6) pada Infeksi COVID-19.

\begin{tabular}{ll}
\multicolumn{1}{c}{ Peneliti dan jenis studi } & \multicolumn{1}{c}{ Tujuan studi } \\
\hline $\begin{array}{l}\text { Chen et al., 2020, } \\
\text { Cina }\end{array}$ & $\begin{array}{l}\text { Mengetahui peranan kadar CRP } \\
\text { dalam menentukan keparahan infeks } \\
\text { Observasional retrospektif }\end{array}$ \\
COVID-19. \\
$\begin{array}{l}\text { Luo et al., 2020, } \\
\text { Observasional restrospektif }\end{array}$ & $\begin{array}{l}\text { Mengevaluasi peran CRP sebagai } \\
\text { prediktor luaran klinis pada pasien } \\
\text { COVID-19. }\end{array}$
\end{tabular}

Sharifpour et al., 2020,

Amerika Serikat

Kohort retrospektif

Mengevaluasi korelasi kadar CRP dengan keparahan dan progresi COVID-19.

Stringer et al., 2021,

Inggris

Kohort retrospektif

Menentukan penggunaan kadar CRP saat awal rawat inap dalam meprediksi mortalitas pada pasien COVID-19.

Liu et al., 2020,

Cina

Kohort retrospektif

Meneliti kemampuan IL-6 dan CRP untuk meprediksi infeksi COVID-19 kriteria ringan dan berat.

Liu et al., 2020,

Cina

Kohort retrospektif
Meneliti peran IL-6 pada COVID-19 kriteria berat.

\section{Temuan studi}

Kadar CRP plasma yang lebih tinggi mengindikasikan pneumonia akibat COVID-19 yang lebih berat dan durasi perawatan yang lebih lama. Kadar CRP plasma berkorelasi positif dengan keparahan pneumonia akibat COVID-19. ${ }^{9}$

Area under the curve CRP $(0,896)$ secara signifkan lebih tinggi dibandingkan parameter lain seperti usia $(0,833)$, hitung neutrofil $(0,820)$ dan hitung trombosit $(0,678)$ dalam memprediksi luaran klinis pasien COVID-19 ( $\mathrm{p}<0,05)$. Kadar CRP memiliki sensitivitas $90,5 \%$ dan spesifisitas $77,6 \%$. Kadar CRP saat awal masuk rumah sakit berkorelasi dengan keparahan penyakit. ${ }^{16}$

Median CRP signifikan lebih tinggi pada pasien COVID-19 yang meninggal dibandingkan yang bertahan hidup [206 mg/L (157$288 \mathrm{mg} / \mathrm{L})$ vs $114 \mathrm{mg} / \mathrm{L}(72-160 \mathrm{mg} / \mathrm{L}), \mathrm{p}<0.001]$. Kadar CRP meningkat secara linier selama minggu pertama rawat inap dan mencapai puncaknya pada hari kelima. Dibandingkan dengan kelompok pasien yang mengalami mortalitas, kelompok pasien yang bertahan hidup memiliki kadar CRP puncak yang lebih rendah dan penurunan kadar CRP yang lebih cepat. ${ }^{8}$

Kadar CRP dengan titik potong $40 \mathrm{mg} / \mathrm{L}$ berhubungan dengan mortalitas pada pasien COVID-19. Nilai ambang batas ini dapat membantu klinisi untuk menggunakan hasil pengukuran CRP dalam monitoring, pengambilan keputusan dan rencana terapi pasien. ${ }^{15}$

Proporsi pasien dengan peningkatan kadar IL-6 dan CRP signifikan lebih tinggi pada kelompok pasien COVID-19 kriteria berat dibandingkan dengan pasien kriteria ringan. Pasien dengan kadar IL-6 >32,1 pg/mL atau CRP >41,8 mg/L lebih berisiko mengalami komplikasi berat. ${ }^{19}$

Nilai baseline IL-6 berhubungan dengan COVID-19 gejala berat. Nilai IL-6 yang tinggi juga berkaitan dengan gambaran CT scan thoraks yang lebih buruk. Penurunan kadar IL-6 yang signifikan ditemukan pada pasien pasca penyembuhan COVID-19. ${ }^{7}$ 
dalam rentang 18-20 jam setelah resolusi stimulus. Peningkatan kadar CRP $>100$ $\mathrm{mg} / \mathrm{L}$ diidentifikasi sebagai prediktor independent dibutuhkannya perawatan di ruang rawat intensif dan juga mortalitas dalam 30 hari pada pasien sepsis. ${ }^{9,20}$ Peningkatan kadar CRP juga ditemukan pada penyakit pernafasan akibat virus. Peningkatan kadar CRP berkorelasi dengan keparahan penyakit dan sebagai prediktor progresi penyakit ke arah lebih buruk. $^{9,20}$ Studi kohort retrospektif oleh Sharifpour et al menemukan bahwa nilai median CRP berkorelasi dengan keparahan COVID-19 dan prediktor terjadinya mortalitas. ${ }^{8}$ Kadar CRP yang meningkat pada tujuh hari pertama rawat inap dapat digunakan sebagai parameter untuk memprediksi progresi penyakit dan dibutuhkannya transfer pasien ke ruang rawat intensif. Karena CRP diketahui berhubungan dengan keparahan infeksi COVID-19, Sharifpour et al menyatakan tingkat kenaikan CRP mengindikasikan perburukan penyakit, selain itu pengukuran CRP merupakan pemeriksaan yang tersedia cukup luas, mudah dilakukan dan relatif terjangkau. ${ }^{8}$ Pengukuran CRP saat awal perawatan dan secara berkala pada pasien COVID-19 rawat inap akan membantu stratifikasi dan prognostikasi pasien COVID-19. Studi oleh Stringer et al juga menemukan kenaikan kadar serum CRP pada pasien dengan infeksi COVID-19 dan membantu triase, diagnostik dan prognostik pasien. ${ }^{15}$ Peningkatan kadar CRP saat awal masuk rumah sakit berhubungan dengan peningkatan mortalitas pasien dan mengindikasikan keparahan penyakit saat awal rawat inap. ${ }^{8}$ Studi terdahulu tersebut merekomendasikan nilai ambang CRP sebesar $40 \mathrm{mg} / \mathrm{L}$ yang optimal untuk peningkatan risiko mortalitas pada pasien COVID-19. ${ }^{8}$

Kaitan antara kadar CRP yang tinggi dengan meningkatnya keparahan infeksi COVID-19 konsisten dengan teori badai sitokin pada infeksi COVID-19.5,6,13 Sistem imunitas bawaan akan melepaskan sitokin inflamasi berupa TNF- $\alpha$, IL- 6 dan IL-1. Studi meta analisis menemukan IL-6 sebagai parameter untuk memprediksi kematian akibat COVID-19 yang terbaik dengan OR sebesar 13,87 dan disusul oleh CRP dengan OR sebesar 7,09. ${ }^{14}$ Namun peningkatan CRP juga tidak hanya berkaitan dengan COVID-19 saja, kondisi patologi lain seperti infeksi pneumonia bakteri sekunder juga dapat berkaitan dengan peningkatan CRP dan sebaiknya dipertimbangkan dalam melakukan penilaian serta keputusan klinis pada pasien., ${ }^{4,6}$

Studi oleh Liu et al menunjukkan bahwa IL-6 dan CRP dapat digunakan sebagai factor prognostik independen terhadap terjadinya COVID-19 kriteria berat. ${ }^{19}$ IL-6 merupakan sitokin multifungsi yang mentransmisikan pensinyalan sel dan regulasi sel imun. IL-6 memiliki efek pro-inflamasi kuat dan memainkan peran penting pada inflamasi, tumor dan penyakit hematologi. ${ }^{19}$ Dari seluruh stitokin proinflamasi, IL-6 merupakan pemicu utama terjadinya badai sitokin. Disebutkan pula bahwa kadar IL-6 yang diambil dari darah perifer pasien dapat digunakan untuk memprediksi progresi infeksi COVID-19. Studi yang dilakukan oleh Liu et al juga menemukan bahwa perubahan kadar IL-6 berhubungan dengan keparahan dan perburukan pada pasien COVID-19 kriteria berat. ${ }^{19}$ Nilai baseline IL-6 yang lebih tinggi berhubungan dengan gambaran CT-scan thoraks yang lebih buruk. Pasien COVID-19 kriteria berat yang membutuhkan perawatan intensif akibat kerusakan paru berat secara konsisten menunjukkan nilai baseline yang lebih tinggi. Studi tersebut juga menyatakan bahwa pengukuran kadar IL-6 dapat menjadi penanda yang bermanfaat untuk monitoring pasien COVID-19 kriteria berat. ${ }^{19,20}$

IL-6 disintesis oleh berbagai sel paru seperti sel makrofag alveolar, pneumosit dan fibroblast. Kadar IL-6 merefleksikan kondisi inflamasi pada paru. Hal ini didukung oleh temuan adanya peningkatan IL-6 pada paru ARDS dan paru yang mengalami komplikasi pasca transplantasi. ${ }^{71}$ Pasien dengan infeksi COVID-19 kriteria berat membutuhkan penatalaksanaan lebih intensif dan memiliki prognosis yang relatif buruk. Peningkatan IL-6 berhubungan dengan keparahan penyakit, karena kadarnya akan turun saat terjadi remisi dan akan meningkat apabila terjadi perburukan infeksi. Oleh karena itu IL-6 merupakan penanda potensial untuk monitoring pasien COVID-19 gejala berat. Penatalaksanaan dengan target IL-6 efektif dalam mengatasi badai sitokin selama progresi infeksi COVID-19 terjadi. ${ }^{7,19}$

\section{Peran Pengukuran D-Dimer sebagai Prediktor Prognosis pada Pasien COVID-19 Kriteria Berat}

Sebuah studi meta analisis oleh Bastug et al menemukan kondisi hiperkoagulasi yang terjadi pada pasien COVID-19 gejala berat terjadi akibat respon hiperinflamasi. ${ }^{21}$ Peningkatan kadar D-dimer dilaporkan sebagai faktor prediktif untuk prognosis yang lebih buruk. Monitoring kadar D-dimer dapat membantu klinisi dalam identifikasi pasien dengan risiko tinggi untuk mengalami COVID-19 kriteria berat. Batas kadar D-dimer yang diajukan sebagai prediktor COVID-19 berat adalah $0.565 \mathrm{mg} / \mathrm{L}$ dengan sensitivitas sebesar $84,7 \%$ dan spesifisitas $80,6 \%$. Studi oleh Li et al menemukan bahwa kenaikan D-dimer pada pasien COVID-19 berhubungan dengan mekanisme imunitas yang abnormal, peningkatan keparahan penyakit dan meningkatnya mortalitas. ${ }^{11}$ Pengukuran D-dimer dapat dilakukan sebagai penanda awal terjadinya perburukan penyakit dan peningkatan risiko kematian. ${ }^{11}$

D-dimer merupakan produk degradasi fibrin berupa fragmen protein kecil yang dilepaskan ke darah Ketika suatu klot pembekuan darah didegradasi oleh proses fibrinolysis. Kadar D-dimer akan meningkat saat sistem koagulasi diaktivasi oleh thrombosis atau pada terjadinya DIC. Kadar D-dimer yang tinggi juga berhubungan dengan keparahan penyakit saat awal perawatan. Terdapat perbedaan signikan antara kesintasan pasien COVID-19 dengan nilai D-dimer yang meningkat dan D-dimer yang normal. Jumlah pasien dengan kadar D-dimer tinggi yang bertahan hidup secara signifikan mengalami penurunan. Peningkatan D-dimer juga berhubungan dengan tingkat mortalitas yang lebih tinggi dengan hazard ratio sebesar 0,88 dengan interval kepercayaan $95 \%{ }^{1}$

Studi oleh Song et al menemukan bahwa D-dimer merupakan penanda yang paling konsisten dalam memprediksi luaran klinis yang buruk pada pasien COVID-19. ${ }^{18}$ 
Tabel 2. Studi terkait peranan D-dimer pada Infeksi COVID-19.

\section{Peneliti dan jenis studi}

Li et al., 2020, Cina

Kohort retrospektif

Song et al., 2020, Cina

Kohort retrospektif

Long et al., 2020, Cina

Kohort retrospektif

\section{Tujuan studi}

Mengevaluasi penggunaan D-dimer

sebagai indicator prognosis pasien

dengan COVID-19.

Meneliti perubahan kadar D-dimer pasca pemberian antikoagulan dan hubungannya dengan mortalitas.

Meneliti peranan indicator koagulasi berupa D-dimer (DD), prothrombin time (PT), activated partial thromboplastin time (APTT), thrombin time (TT), dan fibrinogen (Fg) dalam memprediksi keparahan dan prognosis COVID-19.

\section{COVID-19.}

\section{Temuan studi}

Pasien dengan kadar D-dimer yang meningkat cenderung membutuhkan perawatan berupa oksigen bertekanan tinggi, antokoagulan, antibiotik dan kebutuhan untuk perawatan di ruang rawat intensif lebih tinggi. Pasien dengan peningkatan D-dimer juga memiliki angka mortalitas yang signifikan lebih tinggi dibandingkan pasien dengan kadar D-dimer normal atau rendah. ${ }^{11}$

Terdapat perbedaan tingkat mortalitas yang signfikan berdasarkan kadar D-dimer pasca pemberian antikoagulan yakni sebesar 49\% untuk kelompok dengan tren D-dimer meningkat, $27 \%$ untuk kelompok dengan tren D-dimer meningkat lalu menurun, $21 \%$ pada kelompok dengan D-dimer rendah kemudian meningkat dan 9\% pada kelompok dengan D-dimer rendah kemudian menurun $(\mathrm{p}<0,001){ }^{18}$

Analisis risiko mortalitas menggunakan kurva ROC menunjukkan AUC untuk D-dimer paling baik dibandingkan parameter koagulasi lainnya dan dapat digunakan sebagai indicator yang signifikan dalam memprediksi mortalitas pada COVID-19. ${ }^{12}$
Studi tersebut menemukan batas nilai ambang D-dimer sebesar $>0,5 \mu \mathrm{g} / \mathrm{ml}$ sebagai prediktor kematian saat rawat inap pada pasien COVID-19. ${ }^{18}$ Temuan tersebut didukung hasil studi oleh Long et al yang menyatakan bahwa parameter D-dimer merupakan parameter koagulasi dengan nilai Area Under the Curve yang paling baik dan dapat digunakan untuk memprediksi mortalitas pada pasien COVID-19. ${ }^{12}$ Hasil studi tinjauan sistematis yang dilakukan oleh Moreno et al menyebutkan bahwa kadar D-dimer pada pasien COVID-19 berhubungan dengan peningkatan keparahan penyakit, terjadinya ARDS dan kematian. ${ }^{10}$ Hasil studi tersebut merekomendasikan dilakukannya pengukuran kadar D-dimer saat awal rawat inap dan setiap 24-48 jam untuk evaluasi adanya gangguan koagulasi sehingga dapat memprediksi progresi dan prognosis pasien dengan infeksi COVID-19 kriteria berat. ${ }^{10}$ Badai sitokin yang terjadi pada pasien COVID-19, utamanya dengan gejala berat menyebabkan kerusakan endotel dan mengaktivasi sistem koagulasi. Hal tersebut menghambat sistem fibrinolitik dan antikoagulan sehingga menimbulkan thrombosis berlebih dan pasien jatuh ke dalam kondisi DIC. Selanjutnya pasien dapat mengalami gangguan mikrosirkulasi yang mengakibatkan terjadinya disfungsi organ multiple. Oleh karena itu deteksi dan koreksi disfungsi sistem koagulasi secara efektif dapat menurunkan tingkat mortalitas. ${ }^{6,18}$

\section{SIMPULAN}

Infeksi COVID-19 memiliki spektrum klinis beragam mulai dari asimtomatik hingga gejala berat. Pada infeksiCOVID-19 gejala berat terjadi badai sitokin akibat respon hiperinflamasi ditandai dengan dilepasnya sitokin pro-inflamasi berlebih seperti IL-6 serta peningkatan CRP sebagai reaktan fase akut. Selain itu terjadi pula kondisi koagulopati yang ditandai dengan peningkatan D-dimer. Terdapat perbedaan kadar CRP, IL-6 dan D-dimer yang signfikan antara pasien COVID-19 dengan gejala ringan dan gejala berat. Peningkatan kadar CRP, IL-6 dan D-dimer juga menunjukkan hubungan signifikan dengan peningkatan keparahan infeksi serta mortalitas.

\section{KONFLIK KEPENTINGAN}

Tidak terdapat konflik kepentingan dalam penulisan tinjauan kepustakaan ini.

\section{ETIKA PENULISAN}

Tinjauan kepustakaan ini telah mengikuti pedoman etik dalam publikasi ilmiah berdasarkan protokol COPE maupun ICMJE.

\section{PENDANAAN}

Tidak ada.

\section{KONTRIBUSI PENULIS}

Seluruh penulis memiliki kontribusi yang sama dalam penulisan tinjauan kepustakaan ini baik dari penyusunan kerangka konsep, pengumpulan data, analisis data, hingga interpretasi hasil dalam bentuk analisis sintesis yang termuat dalam narasi ilmiah.

\section{DAFTAR PUSTAKA}

1. Zhou F, Yu T, Du R, Fan G, Liu Y, Liu Z, Cao B. Clinical course and risk factors for mortality of adult inpatients with COVID-19 in Wuhan, China: a retrospective cohort study. Lancet. 2020;395(10229):1054-1062.

2. Ganesh B, Rajakumar T, Malathi M, Manikandan N, Nagaraj J, Santhakumar A, et al. Epidemiology and pathobiology of SARSCoV-2 (COVID-19) in comparison with SARS, MERS: An updated overview of current knowledge and future perspectives. Clin Epidemiol Glob Health. 2021;10:100694.

3. Kemenkes RI. Situasi Terkini Perkembangan Novel Coronavirus (COVID-19). Kementerian Kesehatan Republik Indonesia. 2021 [Data dapat diakses dari: https://covid19. kemkes.go.id/situasi-infeksi-emerging/infocoronavirus/situasi-terkiniperkembangancoronavirusdisease-covid-19-28september2021/\#.X0y2bNwzZxQl.

4. Mousavi-Nasab SD, Mardani R, Nasr Azadani H, Zali F, Ahmadi Vasmehjani A, Sabeti S, et al. Neutrophil to lymphocyte ratio and C-reactive protein level as prognostic markers in mild 
versus severe COVID-19 patients. Gastroenterol Hepatol Bed Bench. 2020;13(4):361-366.

5. Vepa A, Bae JP, Ahmed F, Pareek M, Khunti K. COVID-19 and ethnicity: A novel pathophysiological role for inflammation. Diabetes Metab Syndr. 2020;14(5):1043-1051.

6. Bohn MK, Hall A, Sepiashvili L, Jung B, Steele S, Adeli K. Pathophysiology of COVID-19: mechanisms underlying disease severity and progression. Physiology (Bethesda). 2020;35(5):288-301.

7. Liu T, Zhang J, Yang Y, Ma H, Li Z, Zhang J, et al. The role of interleukin- 6 in monitoring severe case of coronavirus disease 2019. EMBO Mol Med. 2020;12(7):e12421.

8. Sharifpour M, Rangaraju S, Liu M, Alabyad D, Nahab FB, Creel-Bulos CM, et al. COVID-19 Quality \& Clinical Research Collaborative. C-Reactive protein as a prognostic indicator in hospitalized patients with COVID-19. PLoS One. 2020;15(11):e0242400.

9. Chen W, Zheng KI, Liu S, Yan Z, Xu C, Qiao Z. Plasma CRP level is positively associated with the severity of COVID-19. Ann Clin Microbiol Antimicrob. 2020;19(1):18.

10. Moreno G, Carbonell R, Bodí M, Rodríguez A. Systematic review of the prognostic utility of D-dimer, disseminated intravascular coagulation and anticoagulant therapy in COVID-19 critically ill patients. Med Intensiva (Engl Ed). 2021;45(1):42-55.
11. Li J, Liu Z, Wu G, Yi M, Chen Y, Li K, et al. $\mathrm{D}$-Dimer as a prognostic indicator in critically ill patients hospitalized with COVID-19 in Leishenshan Hospital, Wuhan, China. Frontiers in Pharmacology. 2020;11:600592.

12. Long H, Nie L, Xiang X, Li H, Zhang X, Fu $\mathrm{X}$, et al. D-dimer and prothrombin time are the significant indicators of severe COVID-19 and poor prognosis. Biomed Res Int. 2020;2020:6159720.

13. Tay MZ, Poh CM, Rénia L, MacAry PA, Ng LFP. The trinity of COVID-19: immunity, inflammation and intervention. Nat rev Immunol. 2020;20(6):363-374.

14. Mojtabavi H, Saghazadeh A, Rezaei N. Interleukin-6 and severe COVID-19: a systematic review and meta-analysis. Eur Cytokine Netw. 2020;31(2):44-49.

15. Stringer D, Braude P, Myint PK, Evans L, Collins JT, Verduri A, et al. The role of C-reactive protein as a prognostic marker in COVID-19. Int J Epidemiol. 2021;50(2):420-429.

16. Luo X, Zhou W, Yan X, Guo T, Wang B, Xia H, et al. Prognostic value of $\mathrm{C}$-reactive protein in patients with coronavirus 2019. Clin Infect Dis. 2020;71(16):2174-2179

17. Vidali S, Morosetti D, Cossu E, Luisi MLE, Pancani S, Semeraro V, et al. D-dimer as an indicator of prognosis in SARS-CoV-2 infection: a systematic review. ERJ Open Res. 2020;6(2):00260-2020.

18. Song X, Ji J, Reva B, Joshi H, Calinawan AP, Mazumdar M, et al. Post-anticoagulant D-dimer is a highly prognostic biomarker of COVID-19 mortality. ERJ Open Res. 2021;7(3):000182021.

19. Liu F, Li L, Xu M, Wu J, Luo D, Zhu Y, et al. Prognostic value of interleukin-6, C-reactive protein, and procalcitonin in patients with COVID-19. J Clin Virol. 2020;127:104370.

20. Huang I, Pranata R, Lim MA, Oehadian A, Alisjahbana B. C-reactive protein, procalcitonin, D-dimer, and ferritin in severe coronavirus disease-2019: a meta-analysis. Ther Adv Respir Dis. 2020;14:1753466620937175.

21. Bastug A, Bodur H, Erdogan S, Gokcinar D, Kazancioglu S, Kosovali BD, et al. Clinical and laboratory features of COVID-19: Predictors of severe prognosis. Int Immunopharmacol. 2020;88:106950.

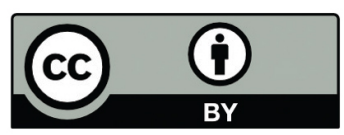

This work is licensed under a Creative Commons Attribution 